\title{
Main factors affecting the loss of multi organ potential donors for transplantation
}

\author{
Principales factores que afectan la pérdida de donantes multi orgánicos potenciales para \\ trasplante
}

\author{
Aldo García-Covarrubias", Luis García-Covarrubias², Dulce A. Alcántara-López', \\ Héctor Hinojosa-Heredia ${ }^{2}$, Paola Prieto-Olivares ${ }^{2}$ and Arturo Reding-Berna/ ${ }^{3}$ \\ ${ }^{1}$ Department of Donation; ' $D$ epartment of Transplants; ${ }^{3}$ Department of Research. Hospital General de México Dr. Eduardo Liceaga, Ciudad de \\ México, Mexico
}

\begin{abstract}
Antecedents: In the field of organ donation and procurement, a possible donor is a patient with severe neurological damage and appropriate medical criteria for donation, and a potential donor is a patient suspected of being brain dead. Objective: The aim of this study is to identify specific factors that cause the loss of possible multiorgan donors in an intensive care unit (ICU). Methods: A review of cross-sectional charts of possible liver and kidney donors was done with patients admitted to the ICU with full respiratory support and Glasgow score $<8$. A multiple logistical regression model was applied to identify the loss of potential donors previously considered only as possible donors. Results: A total of 44 charts were reviewed, 26 were possible, and 18 were potential donors. The mean average was 46.7 and 52.8 years for possible and potential donors, respectively ( $p$ $=0.272$ ). The potential donors experienced frequent intracranial hemorrhage (19.2 vs. 55.6) or renal injury (3.9 vs. 27.8), and fewer invasive procedures are performed (34.6 vs. 5.6) $(p<0.05)$. Invasive procedure resulted significant $(p=0.013)$ when a multivariate analysis was done. Discussion and conclusions: Patients submitted to invasive procedures have 20 times more probabilities of being lost as kidney donors even when originally considered as possible donors. Medical or surgery procedures are the leading cause for the loss of potential donors, so an opportune detection is essential.
\end{abstract}

KEY WORDS: Potential. Possible. Kidney. Donors. Lost.

\section{Resumen}

Antecedentes: En el campo de la donación y la procuración renal, un posible donador es un paciente con daño neurológico grave y que cubre los criterios médicos para la donación; un potencial donador es el paciente que, además, cuenta con la sospecha de tener muerte cerebral. Objetivo: Identificar los factores específicos que causan la pérdida de posibles donadores multiorgánicos en una unidad de terapia intensiva. Metodología: Se realizó un estudio retrospectivo transversal de los expedientes de los posibles donadores de riñón e hígado admitidos a la unidad de terapia intensiva con soporte respiratorio total y escala de Glasgow < 8. Se aplicó un modelo de regresión logística para identificar los casos perdidos de potenciales donadores previamente considerados solo como posibles donadores. Resultados: Se revisaron 44 casos, 26 de posibles y 18 de potenciales donadores. La edad promedio fue de 46.7 y 52.8 años para los posibles y potenciales donadores, respectivamente $(p=0.272)$. Los potenciales donadores experimentaron con más frecuencia hemorragia intracraneal (19.2 vs. 55.6) o lesión renal (3.9 vs. 27.8), y fueron sometidos a menos procedimientos médicos (34.6 vs. 5.6) ( $p<0.05)$. En el análisis multivariado, la realización de algún procedimiento invasivo fue significativa entre los dos grupos ( $p=0.013)$. Discusión y conclusiones: Los pacientes sometidos a un procedimiento invasivo tienen 20 veces más probabilidades de

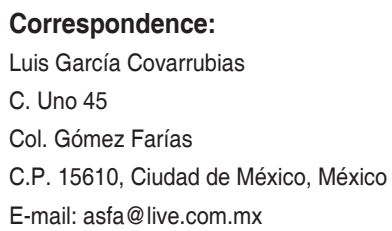

Date of reception: 21-12-2017

Date of acceptance: 12-04-2018

DOI://dx.doi.org/10.24875/CIRU.M18000026
Cir Cir. 2018:86:157-160

Contents available at PubMed www.cirugiaycirujanos.com 
perderse como donadores renales aun siendo considerados de manera original como posibles donadores. Los procedimientos médicos o quirúrgicos son la principal causa de pérdida de potenciales donadores, por lo que es esencial una detección precoz y oportuna de los mismos.

PALABRAS CLAVE: Potencial donador. Posible donador. Riñón. Pérdida donadores.

\section{Background}

The disparity between the number of donors and the number of people waiting for a transplant remains a major problem worldwide. All the transplants performed in the world correspond to $<10 \%$ of those needed. In the field of organ donation and procurement, a possible donor is a patient with severe neurological damage and appropriate medical criteria for donation, and a potential donor is a patient suspected of being brain dead. Such a patient becomes an eligible donor when the diagnosis of brain death has confirmed ${ }^{1,2}$.

Few studies have attempted to look for the main factors that lead to loss of potential donors in the intensive care units (ICUs). Brain death is a process that leads to a cascade of harmful pathophysiological phenomena and significant organ dysfunction. Thus, if too much time elapses between brain death and its confirmation, certain patients who first appeared to be excellent donors end up being marginal or even inadequate ${ }^{3,4}$.

A major drawback is that in many ICUs, patient management focused on multiple organ donation potentials, has little or no priority at all ${ }^{5}$. Furthermore, the hospital must first have established that the potential of multiorgan donor should be admitted to the ICU. In addition, it is essential for the ICU staff to have knowledge of the pathophysiology and management of the patients with confirmed brain death ${ }^{6-8}$.

Spain is recognized as one of the countries with the highest rate of organ donation, with 36 donors per million inhabitants, in contrast, Mexico, only has a rate of four donors per million inhabitants ${ }^{9}$. One of the main developments that made Spain a leader in donation and transplantation was the implementation of the Quality Assurance Program in $1996^{\circ}$. This program has three main purposes: to define the theoretical capacity of each hospital to generate donors, to detect and analyze leaks of potential donors during the process, and to describe the factors that impact the hospital during the donation process ${ }^{9-11}$.

However, Mexico has no equivalent program to improve the effectiveness of organ donation. The aim of this study is to identify the specific factors that cause the loss of possible multiorgan donors and to recommend procedures that will lead to more possible donors becoming potential donors in the ICU of a Mexican public hospital.

\section{Materials and methods}

A retrospective, transversal (cross-sectional) study in which 44 possible kidney and liver donor charts was reviewed from March 1, 2015, to July 1, 2015. All patients were admitted to the ICU of Mexico's General Hospital "Dr. Eduardo Liceaga", all had full respiratory support and a Glasgow coma scale (GCS) < 7. Patients without full respiratory support or GCS $>8$ were excluded.

\section{Statistical analysis}

Age and length of hospital stay (LOS) are reported as mean (standard deviation). Categorical variables, such as gender, diagnosis, with/without sepsis, infection, use of antimicrobials, renal injury, hepatic injury, and neurological damage (no damage or moderate/serious damage), are reported with frequency and percentage. T-student test was used for sex and LOS. Pearson's Chi-square test was used for categorical variables to identify statistically significant differences between possible but not potential donors and potential donors. A multiple logistical regression model was applied to identify variables associated with the loss of potential organ donors after these patients were considered as possible donors. Explanatory variables which were analyzed in this model were: age, sex, LOS, diagnosis, sepsis, infection, use of antimicrobials, renal damage, hepatic damage, and neurological damage. All statistical analyses were performed using STATA version 14.

\section{Results}

A total of 44 charts were reviewed, of which 26 were possible but not potential donors and 18 were potential donors. Mean age was 46.7, 52.8, and 51.5 years for possible donors, potential donors, and all patients, respectively $(p=0.272)$. When comparing LOS, we found a mean of $8.5 \pm 5.9$ days for possible and 10.1 \pm 7.1 for potential donors $(p=0.420)$. 
Comparing possible donors, potential donors presented more frequently with intracranial hemorrhage (19.2 vs. 55.6 ), renal injury (3.9 vs. 27.8$)$, and they had less invasive procedures performed (34.6 vs. 5.6). These data showed statistical significance with $p<0.05$. No statistically significant differences were found for age, sex, LOS, sepsis, infection, antimicrobials, and neurological damage (Table 1).

With the multiple logistic regression models, the factors associated to the loss of potential kidney donors after being considered possible donors were analyzed. Due to the high correlation between some explanatory variables originally included in the model and that some variables had no statistical significance to $95 \%$ confidence, in the end, the model included only age, sex, and diagnosis. In the diagnosis group, the invasive procedure variable resulted to be statistically significant with an odds ratio $=20.2(p=0.013)$ when comparing it to those having an intracranial hemorrhage (Table 2).

\section{Discussion}

One reason why there is a shortage of multiorgan donors in Mexico is that patients with severe neurological damage are not always promptly identified as potential donors or that the organs deteriorate and get infected before the formal declaration of death. Furthermore, although immediate notification about potential organ donors to an organ procurement organization is essential, this is not always done. This is similar to studies in other developing countries and differs markedly from what happens in developed countries ${ }^{12,13}$, where several organ procurement organizations have developed recognition tools. As an example, the Organ Procurement and Transplantation Network in the USA developed the term "Imminent neurological death"14. This definition is solely used for data submission and analysis, not for clinical use as an identification tool, and does not use the GCS which is based on numerous studies like ours.

In this paper, the overall results indicate that patients submitted to invasive procedures have 20 times more probabilities of being lost as kidney donors even when originally considered as possible donors. One thing that stands out in our study is the large number of infectious processes that are detected in very early stages, which is characteristic in developing countries, data not reported in other similar studies, a fact which brings as a consequence a great loss of possible and potential organ donors.

Based in the results, we think that the use of a clinical tool in the form of "imminent brain death" as in
Table 1. Demographic characteristics of patients in the ICU classified as possible and potential kidney donors

\begin{tabular}{|c|c|c|c|}
\hline $\begin{array}{l}\text { Demographic } \\
\text { characteristics }\end{array}$ & $\begin{array}{l}\text { Possible } \\
(n=26)\end{array}$ & $\begin{array}{l}\text { Potential } \\
(n=18)\end{array}$ & $p$ value \\
\hline \multicolumn{4}{|l|}{ Gender } \\
\hline Female & $14(53.9)$ & $13(72.2)$ & \multirow[t]{2}{*}{0.218} \\
\hline Male & $12(46.2)$ & $5(27.8)$ & \\
\hline \multicolumn{4}{|l|}{ Diagnosis } \\
\hline Medical/surgical & $9(34.6)$ & $1(5.6)$ & \multirow[t]{5}{*}{$0.039^{*}$} \\
\hline procedure & $8(30.8)$ & 4 (22.2) & \\
\hline CNS tumors & $4(15.4)$ & $3(16.7)$ & \\
\hline Head trauma & $5(19.2)$ & $10(55.6)$ & \\
\hline $\begin{array}{l}\text { Intracranial } \\
\text { hemorrhage }\end{array}$ & & & \\
\hline \multicolumn{4}{|l|}{ Sepsis } \\
\hline No & $14(53.9)$ & $9(50.0)$ & \multirow[t]{2}{*}{0.802} \\
\hline Yes & $12(46.2)$ & $9(50.0)$ & \\
\hline \multicolumn{4}{|l|}{ Infection source } \\
\hline No & $13(50.0)$ & $8(44.4)$ & \multirow[t]{4}{*}{0.687} \\
\hline Lungs & $5(19.2)$ & $4(22.2)$ & \\
\hline Urinary & $4(15.4)$ & $3(16.7)$ & \\
\hline CNS or abdomen & $4(15.4)$ & $3(16.7)$ & \\
\hline \multicolumn{4}{|l|}{ Antimicrobials } \\
\hline No & $9(34.6)$ & $6(33.3)$ & \multirow[t]{2}{*}{0.930} \\
\hline Yes & $17(65.4)$ & $12(66.7)$ & \\
\hline \multicolumn{4}{|l|}{ Renal injury } \\
\hline No & $25(96.2)$ & $13(72.2)$ & \multirow[t]{2}{*}{$0.023^{*}$} \\
\hline Yes & $1(3.9)$ & $5(27.8)$ & \\
\hline \multicolumn{4}{|l|}{ Altered LFTs } \\
\hline No & $22(84.6)$ & $18(100.0)$ & \multirow[t]{2}{*}{0.081} \\
\hline Yes & $4(15.4)$ & $0(0)$ & \\
\hline \multicolumn{4}{|l|}{ Neurological damage } \\
\hline None/moderate & $0(0.0)$ & $1(5.6)$ & \multirow[t]{2}{*}{0.224} \\
\hline Severe & $26(100.0)$ & $17(94.4)$ & \\
\hline
\end{tabular}

Categorical variables are shown as absolute and relative frequency (\%) including Pearson's $\chi^{2}$. *Statistically significant.

LFTs: liver function tests, CNS: central nervous system, ICU: intensive care unit.

Table 2. Logistic regression model of factors associated with the loss of kidney donors

\begin{tabular}{lccc}
\hline Variable & OR & $\mathbf{( 9 5 \% ~ C l )}$ & $\boldsymbol{p}$ value \\
\hline Age & 0.99 & $(0.95-1.03)$ & 0.619 \\
Gender & & & \\
$\quad$ Female & & & \\
$\quad$ Male & 1.00 & & \\
Diagnosis & 2.54 & $(0.56-11.56)$ & 0.230 \\
$\quad$ Intracranial & & & \\
hemorrhage & 1.00 & & \\
$\quad$ Trauma & 2.05 & $(0.30-14.18)$ & 0.467 \\
$\quad$ CNS tumors & 2.91 & $(0.53-15.89)$ & 0.219 \\
Invasive procedure & 20.20 & $(1.87-217.68)$ & $0.013^{*}$ \\
Constant & & & \\
CNS: central nervous system, OR: odds ratio, Cl: confidence interval &
\end{tabular}

${ }^{*} p$ value $<0.05$ significant. 
previous retrospective chart analysis ${ }^{15}$, is the most practical tool for identifying patients who are likely to soon become brain dead, and therefore, for identifying patients most likely to become organ donors ${ }^{13}$.

\section{Conclusions}

The delay in identification of possible donors, particularly following a medical or surgical procedure, was the leading cause of loss of potential donors. Rapid identification of possible donors can prevent the appearance of systemic infectious diseases and thus increase the actual and potential donor pool. Several initiatives have been undertaken to increase the frequency of organ donation such as the initiation of presumed consent legislation, improved attention to the request procedures, and improved awareness of ICU physicians and ICU nurses in the recognition and identification of possible organ donors.

We recommend the creation of an effective an effective interagency protocol in which we can act in a timely manner to detect possible organ donors. We also propose formalizing the role of transplant coordinators, who will be present at all times to give information, answer questions, explore donation-related issues, and provide emotional support.

\section{Acknowledgments}

We acknowledge Academic Writing Workshop (UNAM) with special thanks to Biol. Katya Frank Ph.D, for providing the grammar and structural support needed for the development of the paper. We also thank David Baldwin Ph.D (UNAM - Canada) for her review of the manuscript.

\section{References}

1. Saidi RF, Markmann JF, Jabbour N, et al. The faltering solid organ donor pool in the united states (2001-2010). World J Surg. 2012;36:2909-13.

2. Rocha I, Frontera JA. Worldwide barriers to organ donation. JAMA Neurol. 2015;72:112-118.

3. Kompanje EJ, Jansen NE, de Groot YJ. In plain language: uniform criteria for organ donor recognition. Intensive Care Med. 2013;39:1492-4.

4. Kutsogiannis D, Pagliarello G, Doig C, Ross H, Shemie S. Medical management to optimize donor organ potential: review of the literature. Can J Anesth. 2006;53:820-30.

5. Jochmans I, Watson CJE. Taking the heat out of organ donation. N Engl J Med. 2015;373:477-8.

6. Dhanani S, Shemie SD. Advancing the science of organ donor management. Crit Care. 2014;18:1-3.

7. Wood KE, Becker BN, McCartney JG, et al. Care of the potential organ donor. N Engl J Med. 2004;351:2731-9.

8. Miller LD, Gardiner ST, Gubler KD. Emergency department referral for organ donation: more organ donors and more organs per donor. Am J Surg. 2014;207:728-34.

9. Cuende N, Cañón JF, Alonso M, Delagebasala CM, Sagredo E, Miranda B. Quality assurance program in the process of donation and transplantation at the national organization of transplantations. Nefrologia. 2001;21 Suppl 4:65-76.

10. de la Rosa G, Domínguez-Gil B, Matesanz R, et al. Continuously evaluating performance in deceased donation: the Spanish quality assurance program. Am J Transpl. 2012;12:2507-13.

11. Opdam HI, Silvester W. Identifying the potential organ donor: an audit of hospital deaths. Intensive Care Med. 2004;30:1390-7.

12. Bos EM, Leuvenink HG, van Goor H, Ploeg RJ. Kidney grafts from brain dead donors: inferior quality or opportunity for improvement? Kidney Int. 2007;72:797-805.

13. Heshmati B, Tavakoli SA, Mahdavi-Mazdeh M, Sobhani Z. Assessment of brain death of organ donors in Iran. Transpl Int. 2010;23:7-9.

14. de Groot YJ, Jansen NE, Bakker J, et al. Imminent brain death: point of departure for potential heart-beating organ donor recognition. Intensive Care Med. 2010;36:1488-94.

15. Domínguez B, Delmonico FL, Shaheen FA, et al The critical pathway for deceased donation: reportable uniformity in the approach to the deceased donation. Transpl Int. 2011;24:373-8. 